\title{
INFLUENCE OF LIQUIID QUENCHING ON PHASE COMPOSITION AND PROPERTIES OF Be-Si EUTECTIC ALLOY
}

\author{
(DValerij F. Bashev*, (DSergey I. Ryabtsev, (D) Oleksandr I. Kushnerov, \\ (D) Nataliya A. Kutseva, (D) Sergey N. Antropov \\ Department of Experimental Physics, Oles Honchar Dnipro National University \\ 72 Gagarin ave., Dnipro, 49010 Ukraine \\ *Corresponding Author: bashev vf@ukr.net \\ Received May 10, 2020; accepted May 24, 2020
}

By the method of quenching from the liquid state (splat-quenching), it is first revealed the formation of mixture of metastable supersaturated substitutional solid solutions in the eutectic alloy Be-33at.\% Si. Cast samples are obtained by pouring melt into a copper mold. High cooling rates during liquid quenching are achieved throw the well-known splat-cooling technique by spreading a drop of melt on the inner surface of a rapidly rotating, heat-conducting copper cylinder. The maximum cooling rates are estimated by the foil thickness. The melt cooling rates (up to $10^{8} \mathrm{~K} / \mathrm{s}$ ), used in the work, are sufficient to form amorphous phases in some eutectic alloys with similar phase diagrams, but it is found those rates are insufficient to obtain them in the Be-Si eutectic alloy. The X-ray diffraction analysis is carried out on a diffractometer in filtered Cobalt $\mathrm{K}_{\alpha}$ radiation. Microhardness is measured on a micro-durometer at a load of $50 \mathrm{~g}$. The electrical properties, namely the temperature dependences of relative electrical resistance, are studied by the traditional 4-probe method of heating in vacuum. The accuracy of determining the crystal lattice period of the alloy, taking into account extrapolation of the reflection angle by $90^{\circ}$, is $\pm 3 \cdot 10^{-4} \mathrm{~nm}$. It is found that even at extremely high rate of quenching from the melt, instead of the amorphous phase formation, the occurrence of two supersaturated substitutional solid solutions, based on Beryllium and Silicon, is revealed. This fact is established by the obtained dependences of their lattice periods values on the alloying element content. So, during the formation of metastable eutectic structure, a supersaturated with Beryllium solid solution of Silicon has period $a=0.5416 \mathrm{~nm}$, and a supersaturated with Silicon solid solution of low-temperature hexagonal Beryllium has periods $a=0.2298 \mathrm{~nm}, c=0.3631 \mathrm{~nm}$. The positive role of the liquid quenching method in increasing the level of mechanical characteristics (microhardness and microstresses) in rapidly cooled Be-Si films is shown. It has been demonstrated that the difference in the atomic radii of the elements significantly affects the distortion of crystal lattices of the formed supersaturated solid solutions, and a significant value of microstresses (second-order stresses) in the Silicon lattice supersaturated with Beryllium is estimated, which, of course, leads to a significant increase in the microhardness, namely: there is an increase in microhardness in the Be-Si alloy under the conditions of applied method of quenching from the liquid state by more than 1.7 times compared to cast eutectic alloy and more than 6 times higher in comparison with the eutectoid cast Iron-Carbon alloy. The obtained polytherm of electrical resistance of the alloy under conditions of continuous heating in vacuum confirms the metastable nature of obtained new phases during quenching from the liquid state.

KEYWORDS: Splat-quenching, eutectic, highly supersaturated solid solution, microhardness, microstresses, temperature coefficient of resistance

Currently, the following approaches are used to obtain new metallic materials with improved characteristics: 1) applying of modern methods of fast crystallization with cooling rates from $10^{6} \mathrm{~K} / \mathrm{s}$ (liquid quenching) to $10^{12} \mathrm{~K} / \mathrm{s}$ (vapor quenching) [1-4]; 2) evaluation of properties of the crystal lattices at the atomic level $[5,6] ; 3)$ the development of multicomponent high-entropy alloys [7,8]; 4) the use of practical experience in quenching methods improving [9].

The application of liquid quenching (LQ) method with cooling rates of up to $10^{8} \mathrm{~K} / \mathrm{s}$ allows one to obtain new metastable states in alloys, including highly supersaturated solid solutions (HSSS) and intermediate metastable phases, in particular, a solid amorphous state, with improved physical characteristics. When considering the effects that occur during the LQ, it is necessary to take into account the type of state diagrams of alloys. Alloys of the Be-Si system have so far been studied in the entire concentration range under standard crystallization conditions. The phase diagram of the Be-Si system is characterized by the presence of simple eutectic at 33 at. $\%$ Silicon, with eutectic temperature $1090^{\circ} \mathrm{C}$, and practically zero mutual solubility of elements in the solid state [10-12] at room temperature. A feature of cast Be-Si alloys is their significant brittleness, even with a small Silicon content in the alloy [10]. It should be noted that Beryllium alloys are currently receiving special attention since Beryllium has a promising combination of many physical characteristics: high specific strength, corrosion resistance, and low density. Therefore, Be-Si alloys in the form of thin films can be used in some modern branches of technology: for example, in X-ray technology as strong foils due to the presence of phases based on Beryllium and Silicon with distorted crystal lattices in the eutectic structure of the alloy due to supersaturation of solid solutions. Beryllium-based alloys are widely used as Beryllium windows in X-ray tubes, allowing to pass the X-rays coming out of the tube with a small loss in intensity and at the same time, due to its strength characteristics, maintain the necessary high vacuum in the X-ray tube. Therefore, the improved strength characteristics of the Be-Si LQ-alloy can contribute to a decrease in the thickness of protective foil with a simultaneous increase in the intensity of the rays emerging from the X-ray tube, and, consequently, to an increase in its working power.

In this work, we investigate the influence of the phase diagram type and the method of rapid quenching from melt on the features of the formation of metastable states and on the improvement of some physical properties, in particular, the microhardness of eutectic Be-Si alloy. 
The Be-Si phase diagram is identical in appearance to a simple eutectic Au-Si phase diagram, in which the mutual solubility of elements at room temperature is also practically absent, however, the eutectic temperature is $720 \mathrm{~K}$ lower than the eutectic temperature in the Be-Si alloy.It should be noted that in the Au-Si eutectic alloy, along with the Pd-Si system, amorphous phases were first obtained by quenching from the liquid state [13]. Therefore, it is of scientific and practical interest to study also the influence of features of the eutectic-type state diagram on the propensity of alloys to form metastable states in them under the conditions of LQ.

\section{MATERIALS AND METHODS}

High cooling rates during LQ were achieved by the well-known splat-cooling technique by spreading a drop of melt on the inner surface of a rapidly rotating, heat-conducting copper cylinder. The maximum cooling rates estimated by the foil thickness were $\sim 10^{8} \mathrm{~K} / \mathrm{s}[13,14]$. The as-cast samples were obtained by pouring the melt into a copper mold. X-ray diffraction analysis (XRD) was carried out on a URS-2.0 diffractometer in filtered cobalt $\mathrm{K}_{\alpha}$ radiation. Microhardness was measured on a PMT-3 microhardness meter at a load of $50 \mathrm{~g}$. The electrical properties, namely the temperature coefficient of electrical resistance and the temperature dependence of electrical resistance were studied by the traditional 4-probe method of heating in vacuum. The accuracy of determining the period of the crystal lattice of the alloy, taking into account extrapolation of the reflection angle by $90^{0}$, was $\pm 3 \cdot 10^{-4} \mathrm{~nm}$.

\section{RESULTS AND DISCUSSION}

As a result of studying the effect of the LQ method on the tendency to form metastable states in a Be-Si eutectic alloy, it was found that even at extremely high (up to $10^{8} \mathrm{~K} / \mathrm{s}$ ) rate of quenching from the melt, in contrast to the Au-Si system, instead of the amorphous phase formation, the occurrence of two supersaturated substitutional solid solutions based on Beryllium and Silicon was recorded. This fact was established by the obtained dependences of the values of their lattice periods on the content of the alloying element. So, during the formation of a metastable eutectic structure, a supersaturated with Beryllium solid solution of Silicon has a period $a=0.5416 \mathrm{~nm}$ (the tabular value of the Silicon lattice period is $a=0.5431 \mathrm{~nm}$ ), and a supersaturated with Silicon solid solution of low-temperature hexagonal Beryllium has periods $a=0.2298 \mathrm{~nm}, c=0.3631 \mathrm{~nm}$ (tabular values of the periods of the Beryllium lattice [15] are respectively: $a=0.2287 \mathrm{~nm}$ and $c=0.3583 \mathrm{~nm}$ ). Due to the absence in the literature of the established dependences on the influence of alloying elements on the periods of the crystal lattices of solid solutions of the substitution type in the Be-Si system, it is difficult to evaluate the composition of supersaturated solid solutions obtained during liquid crystal cooling.

Previously, numerous experiments have established criteria that contribute to the formation at LQ of amorphous phases in eutectic alloys, which, in particular, include the temperature criterion: the criterion of "deep eutectic". An analysis of this criterion showed that if for an $\mathrm{Au}-\mathrm{Si}$ eutectic alloy, a drop in the liquidus temperature by 1 at.\% of the alloying element for the left (on the Gold side) and right (on the Silicon side) branches of the phase diagram is $23 \mathrm{~K} / \mathrm{at} . \%$ and $15 \mathrm{~K} / \mathrm{at} . \%$ respectively, then for the studied Be-Si eutectic alloy, this drop is respectively $6 \mathrm{~K} /$ at.\% (from the Beryllium side) and $5 \mathrm{~K} /$ at.\% (from the Silicon side). The lower slope of the liquidus lines for the Be-Si alloy and the higher temperature of eutectic reaction naturally lead to the realization of lower value of supercooling of this melt achieved at LQ, which, in turn, does not allow, due to the relatively high viscosity under the indicated temperature conditions of supercooled melt, transfer the Be-Si melt to a solid amorphous state at LQ. At the same time, the level of supercooling achieved was sufficient for the formation of a Be-Si eutectic alloy in the structure due to a change in the corresponding distribution coefficients at the crystallization front of two supersaturated substitutional solid solutions based on Silicon and Beryllium (the atomic radii of Silicon and Beryllium are respectively: $a=0.117 \mathrm{~nm}$ and $a=0.113 \mathrm{~nm}$ ). The indicated difference in the atomic radii of elements, as it's turned out, significantly affects the distortion of crystal lattices of the formed supersaturated solids, for example, the magnitude of microstresses $\Delta a / a$ (second-order stresses) in the Silicon lattice supersaturated with Beryllium, estimated according to the proposed expression in the approximation method [16] $(\Delta a / a=\beta / 4 \cdot \operatorname{tg} \Theta$, where $\beta-$ is the integral half-width of diffraction line; $\Theta$ - is the angle of reflection from the line (531)), has a significant value which is equal to $\Delta a / a=3.45 \cdot 10^{-3}$. This fact, of course, naturally leads to a significant increase in the microhardness $\left(H_{\mu}\right)$, so if for a cast eutectic alloy the value $H_{\mu}=4100 \mathrm{MPa}$, then for the Be-Si LQ-alloy this value already averages $6900 \mathrm{MPa}$, i.e. an increase in microhardness in this alloy is observed under the conditions of the applied LQ method by more than 1.7 (Fig.1). This makes it possible to classify the Be-Si LQ-alloy within the reduced microhardness $H_{\mu} / \rho$ ( $\rho-$ is the alloy density) to very hard metal alloys: for example, in a eutectoid cast Iron-Carbon alloy, such microhardness is more than 6 times lower.

The metastable nature of supersaturated solid solutions obtained is also confirmed by the results of the heat treatment when heated to $973 \mathrm{~K}$, namely: the crystal lattice period of a supersaturated Silicon-based solid solution increases to $0.5422 \mathrm{~nm}$ due to its decay and, therefore, less supersaturation of Silicon lattice with Beryllium, and with a corresponding reduction in the degree of tension of Silicon lattice up to $\Delta a / a=2.79 \cdot 10^{-3}$. Unfortunately, it is very difficult to obtain experimentally such dependencies of microstresses at large reflection angles for the lattice of a supersaturated solid solution based on Beryllium due to the low reflectivity of X-rays from Beryllium and "shading" of adjacent reflection lines from the Silicon lattice on the X-ray diffraction pattern. 


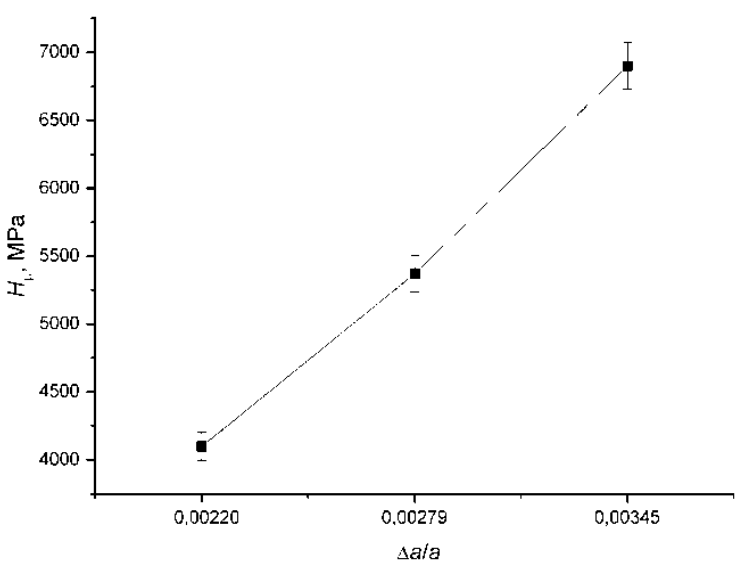

Figure 1. The dependence of microhardness value $H_{\mu}$ on magnitude of microstresses $\Delta a / a$

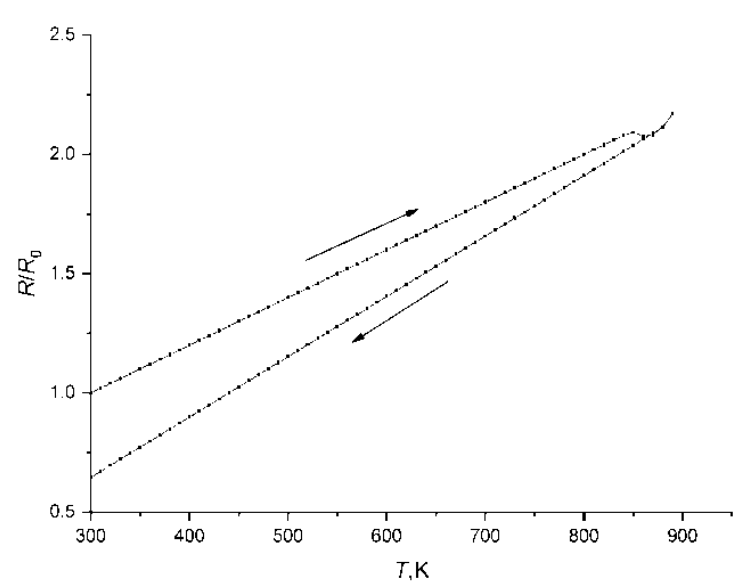

Figure 2. Temperature dependence of relative electrical resistance of the eutectic Be-Si LQ alloy

Additional confirmation of the metastable nature of phases obtained at $\mathrm{LQ}$ is the received temperature dependence of electrical resistance of the alloy under conditions of continuous heating in a vacuum (Fig.2). It can be seen that only at a temperature of $860 \mathrm{~K}$, an inflection is observed, associated with the decomposition of a supersaturated Siliconbased solid solution, indicating a high temperature stability of the metastable state of the Be-Si alloy that appeared during the LQ. It should be noted that the temperature coefficient of resistance (TCR) of eutectic Be-Si LQ-alloy is characterized by a significant decrease: for example, if for cast Beryllium and Silicon samples it is $6.6 \cdot 10^{-3} \mathrm{~K}^{-1}$ and $(-1,8) \cdot 10^{-3} \mathrm{~K}^{-1}$ respectively, then for the Be-Si LQ-alloy after annealing, the TCR is in the range of $\sim 2 \cdot 10^{-3} \mathrm{~K}^{-1}$. It should be noted that, in comparison with the cast state, the metastable structure of eutectic Be-Si LQ-alloy is characterized by a slight increase in its ductility, which is expressed in the possibility of plastic deformation of LQ-foils.

\section{CONCLUSIONS}

It is established that, as a result of quenching from a liquid state of eutectic Be-Si alloy, the spectrum of obtained metastable states expands in comparison with the traditional method for producing cast alloys.

The values of crystal lattice periods of supersaturated substitutional solid solutions based on Beryllium and Silicon are determined. The essential role of the temperature criterion of "deep eutectics" on the tendency of simple eutectic alloys to form a solid amorphous or nanocrystalline state in them is confirmed. The positive role of the stressed state of crystal lattices of solid solutions due to the difference in the atomic radii of Beryllium and Silicon by a significant increase in the level of microstresses and microhardness in the Be-Si LQ- alloy, as well as some improvement in its plastic characteristics, is noted.

\section{Declaration of interest none.}

\section{ORCID IDs}

Valerij F. Bashev, https://orcid.org/0000-0002-3177-0935; (Dergey I. Ryabtsev, https://orcid.org/0000-0002-2889-5278

DOleksandr I. Kushnerov, https://orcid.org/0000-0002-9683-2041; (i) Nataliya A. Kutseva, https://orcid.org/0000-0002-6580-120X

(DD Sergey N. Antropov, https://orcid.org/0000-0002-3248-6389

\section{REFERENCES}

[1] V.F. Bashev, O.I. Kushnerov, E.V. Il'chenko, S.I. Ryabtsev, N.A. Kutseva, and A.A. Kostina, Metallofizika i Noveishie Tekhnologii, 40(9), 1231-1245 (2018), https://doi.org/10.15407/mfint.40.09.1231.

[2] S. Ryabtsev, P. Gusevik, V. Bashev, and F. Dotsenko, J. Mater. Sci. Eng. A2(9), 648-653 (2012).

[3] F.F. Dotsenko, V.F. Bashev, S.I. Ryabtsev, and A.S. Korchak, Phys. Met. Metallogr. 110(3), 223-228 (2010). (in Russian), https://doi.org/10.1134/S0031918X1009005X.

[4] S.I. Ryabtsev, V.F. Bashev, A.I. Belkin, and A.S. Ryabtsev, The Physics of Metals and Metallography, 102(3), 305-308 (2006).

[5] Z.A. Matysina, D.V.Schur, S.N.Antropov, and S.Yu. Zaginaichenko, Metallofizika i Noveishie Tekhnologii, 29(7), 909-936 (2007).

[6] F.E. Wang, Bonding Theory for Metals and Alloys, 2nd Ed. (Elsevier, 2018), p. 230.

[7] V.F. Bashev, and O.I. Kushnerev, The Physics of Metals and Metallography, 115(7), 692-696 (2014), https://doi.org/10.1134/S0031918X14040024.

[8] V.F. Bashev, and O.I. Kushnerev, The Physics of Metals and Metallography, 118(1), 39-47 (2017), https://doi.org/10.1134/S0031918X16100033.

[9] E.S. Skorbyaschensky, V.F. Bashev, A.N. Polishko, and S.N. Antropov, Journal of Physics and Electronics, 27(2), 51-54 (2019)

[10] A.E. Vol, Строение и свойства двойных металлических систем. Т.1: Физико-химические свойства элементов системы азота, актиния, алюминия, америция, бария, бериллия, бора T.1 [Structure and properties of binary metal systems. Vol.1: Physico-chemical properties of elements of the system of nitrogen, actinium, aluminum, americium, barium, beryllium, boron Vol.1 (Fiz.-Mat. Lit., Moscow, 1959), Vol. 1, p.755. (in Russian). 
[11] T.B. Massalskii, Binary Alloy Phase Diagrams, (ASM International, Materials Park, Ohio, USA, 1990).

[12] M. Khansen, K. Anderko, Структуры двойных сплавов [Structures of double alloys], (Publishinghouse NTL, Moscow, 1962). (in Russian).

[13] I.S.Miroshnichenko,Закалка изжидкого состояния[QuenchingFromTheLiquidState],(Metallurgy,Moscow,1982).(in Russian)

[14] V.K. Nosenko, A.Yu. Rudenko, T.N. Moiseeva, V.V. Maksimov, M.S. Nizameev, A.I. Limanovskiy, A.M. Semirga, and V.I. Tkatch, Metallofizika i Noveishie Tekhnologii, 37(12), 1681 (2015).

[15] G.V. Samsonov, Свойства элементов. Ч.1 [Properties of the elements. Ch.1], (Metallurgy, Moscow, 1976), Ch.1. p. 599.

[16] S.S. Gorelik, Yu.A. Skakov, and L.N. Rastorguev, Рентгенографический и электронно-оптический анализ [X-ray апd electron-optical analysis], (Moskva:MISIS:2002). (in Russian).

\section{ВПЛИВ ЗАГАРТУВАННЯ З РІДКОГО СТАНУ НА ФАЗОВИЙ СКЛАД І ВЛАСТИВОСТІ ЕВТЕКТИЧНОГО СПЛАВУ Ве-Sі}

В.Ф. Башев, С.І. Рябцев, О.І. Кушнерьов, Н.А. Куцева, С.М. Антропов

Кафедра експериментальної фізики, Дніпровський начіональний університет імені Олеся Гончара

72 пр. Гагаріна, Дніпро, 49010 Україна

Методом гарту з рідкого стану (splat-загартування) вперше виявлено утворення суміші метастабільних пересичених твердих розчинів заміщення в евтектичному сплаві Be-33at.\% Si. Литі зразки отримують шляхом заливки розплаву в мідну форму. Високі швидкості охолодження під час рідинного загартування досягаються завдяки відомій техніці splat-охолодження, коли крапля розплаву розподіляється на внутрішній поверхні швидко обертового теплопровідного мідного циліндра. Максимальні швидкості охолодження оцінюються по товщині фольги. Використовувані в роботі швидкості охолодження розплаву (до $10^{8} \mathrm{~K} / \mathrm{s}$ ) достатні для утворення аморфних фаз в деяких евтектичних сплавах 3 аналогічними фазовими діаграмами, але встановлено, що ці швидкості недостатні для отримання таких фаз в евтектичному сплаві Be-Si. Рентгеноструктурний аналіз проводиться на дифрактометрі у відфільтрованому випромінюванні кобальту К $\alpha$. Мікротвердість вимірюється на мікротвердомірі при навантаженні 50 Г. Електричні властивості, а саме, температурні залежності відносного електричного опору, вивчаються традиційним 4-зондовим методом нагріву в вакуумі. Точність періоду кристалічної решітки сплаву з урахуванням екстраполяції кута відображення на $90^{0}$ становить $\pm 3 \cdot 10^{-4}$ нм. Виявлено, що навіть при надзвичайно високій швидкості гарту з розплаву замість утворення аморфної фази виявляється наявність двох пересичених твердих розчинів заміщення на основі Берилію і Кремнію. Продемонстровано, що різниця в атомних радіусах елементів істотно впливає на спотворення кристалічних решіток пересичених твердих розчинів, що формуються, і оцінена значна величина мікронапруг (напруг другого роду) в решітці Кремнію, яка пересичена Берилієм, що, природно, і обумовлює суттєве зростання величини мікротвердості, а саме: спостерігається збільшення мікротвердості у Be-Si сплаві в умовах застосованого методу загартування з рідкого стану більш, ніж в 1,7 рази в порівнянні 3 литим евтектичним сплавом і більш ніж в 6 разів вище в порівнянні з евтектоїдним литим сплавом Залізо-Вуглець. Отримана політерма електроопору сплаву в умовах безперервного нагріву його в вакуумі підтверджує метастабільний характер сформованих нових фаз при загартуванні з рідкого стану.

КЛЮЧОВІ СЛОВА: гарт 3 розплаву, евтектика, мікротвердість, пересичений твердий розчин, мікронапруги, температурний коефіцієнт опору

\section{ВЛИЯНИЕ ЗАКАЛКИ ИЗ ЖИДКОГО СОСТОЯНИЯ НА ФАЗОВЫЙ СОСТАВ И СВОЙСТВА ЭВТЕКТИЧЕСКОГО СПЛАВА Ве-Si}

В.Ф. Башев, С.И. Рябцев, А.И. Кушнерев, Н.А. Куцева, С.Н. Антропов

Кафедра экспериментальной физики, Днепровский национальный университет имени Олеся Гончара 72 пр. Гагарина, Днепр, 49010 Украина

Методом закалки из жидкого состояния (splat-закалка) впервые выявлено образование смеси метастабильных пересыщенных твердых растворов замещения в эвтектическом сплаве Be-33at.\%Si. Литые образцы получают путем заливки расплава в медную форму. Высокие скорости охлаждения во время жидкостного закаливания достигаются благодаря известной технике splat-охлаждения, путем размазывания капли расплава на внутренней поверхности быстро вращающегося теплопроводящего медного цилиндра. Максимальные скорости охлаждения оцениваются по толщине фольги. Используемые в работе скорости охлаждения расплава (до $10^{8} \mathrm{~K} / \mathrm{s}$ ) достаточны для образования аморфных фаз в некоторых эвтектических сплавах с аналогичными фазовыми диаграммами, но установлено, что эти скорости недостаточны для их получения в эвтектическом сплаве $\mathrm{Be}-\mathrm{Si}$. Рентгеноструктурный анализ проводится на дифрактометре в отфильтрованном излучении кобальта $\mathrm{K}_{\alpha}$. Микротвердость измеряется на микротвердомере при нагрузке 50 Г. Электрические свойства, а именно, температурные зависимости относительного электрического сопротивления, изучаются традиционным 4-зондовым методом нагрева в вакууме. Точность определения периода кристаллической решетки сплава с учетом экстраполяции угла отражения на $90^{0}$ составляет $\pm 3 \cdot 10^{-4}$ нм. Обнаружено, что даже при чрезвычайно высокой скорости закалки из расплава вместо образования аморфной фазы обнаруживается наличие двух пересыщенных твердых растворов замещения на основе Бериллия и Кремния. Продемонстрировано, что разница в атомных радиусах элементов существенным образом влияет на искаженность кристаллических решеток формирующихся пересыщенных твердых растворов, и оценена значительная величина микронапряжений (напряжений второго рода) в решетке Кремния, пересыщенной Бериллием, что, естественно, и обусловливает существенный рост величины микротвердости, а именно: наблюдается увеличение микротвердости в $\mathrm{Be}-\mathrm{Si}$ сплаве в условиях примененного метода закалки из жидкого состояния более, чем в 1,7 раза по сравнению с литым эвтектическим сплавом и более чем в 6 раз выше в сравнении с эвтектоидным литым сплавом Железо-Углерод. Полученная политерма электросопротивления сплава в условиях непрерывного нагрева его в вакууме подтверждает метастабильный характер сформированных новых фаз при закалке из жидкого состояния.

КЛЮЧЕВЫЕ СЛОВА: закалка из расплава, эвтектика, пересыщенный твердый раствор, микротвердость, микронапряжения, температурный коэффициент сопротивления 